Available online at GSC Online Press Directory

GSC Biological and Pharmaceutical Sciences

e-ISSN: 2581-3250, CODEN (USA): GBPSC2

Journal homepage: https://www.gsconlinepress.com/journals/gscbps

(RESEARCH ARTICLE)

\title{
Effects of dehydration and subsequent hydration stress on the cerebral neurosecretory cells of Eudrilus eugeniae (Kinberg, 1867)
}

\author{
Bhattacharjee Anurag and Chaudhuri Priyasankar* \\ Department of Zoology, Earthworm Research Laboratory, Tripura University, Suryamaninagar-799022, Tripura, India.
}

Publication history: Received on 02 May 2020; revised on 06 May 2020; accepted on 07 May 2020

Article DOI: https://doi.org/10.30574/gscbps.2020.11.2.0124

\begin{abstract}
Moisture is a limiting factor for the survival and distribution of earthworms. During rainy season earthworms come out from their water-filled burrows and during summer move deeper into the soil to prevent acute desiccational water loss. Moisture loving worms like Eudrilus eugeniae when subjected to the dry soil and then subsequently hydrated, both the types of neurosecretory cells (A and B cells) show contrasting neurosecretory changes. During dehydration stress (2, 4 \& 6 hours), both A and B cells deplete, lose their cellular conformity with extensive vacuolation. But in subsequent hydration of desiccated worms for $4 \mathrm{hrs}$, there is accumulation of neurosecretory materials in both types of cells, chiefly in A cells. The result indicates involvement of both A and B neurosecretory cells during osmotic stress from the perspective of histomorphic variations and secretory dynamics.
\end{abstract}

Keywords: Cerebral ganglion; Earthworm; Eudrilus eugeniae; Dehydration; Hydration; Neurosecretory cells.

\section{Introduction}

Earthworms are often exposed to the events like flooding of water during rainy season and also face the problem of acute desiccational water loss during summer. In fact, the activity of earthworm depends upon the moisture content of the soils as water constitutes $75-90 \%$ of the body weight of earthworms [1]. Under extreme drought condition the earthworms move deeper inside the soils but in monsoon after a heavy rain or flood they come out from their waterfilled burrows.

The earthworms do not possess any epithelial endocrine gland. Any kind of physiological activity such as osmoregulation, thermal acclimation, etc. is under the control of neurosecretion [2, 3]. So it is reasonable that earthworms subjected to osmotic stress like dehydration and subsequent hydration is overcome by the secretion of the neurohormone from the central nervous system neurosecretory cells of earthworms.

Eudrilus eugeniae (Kinberg, 1867), native to South African savannah soils is popularly known as the "African nightcrawler". It is widely used as vermicomposting worm in the tropical countries. E. eugeniae has water content of 83.9\% [4] and can tolerate moisture between 70\%-80\% [5]. Dehydration in this moisture loving earthworm can jeopardize the osmotic concentration of the body fluid which probably instigates alterations in the functional activity of its cerebral neurosecretory system.

So the aim of our present paper is to study the effects of dehydration and subsequent hydration stress on the cytomorphological changes in the cerebral neurosecretory system in Eudrilus eugeniae (Eudrilidae).

\footnotetext{
${ }^{*}$ Corresponding author: Chaudhuri Priyasankar
} 


\section{Material and methods}

Twenty five clitellate Eudrilus eugeniae (average length $25.4 \mathrm{~cm}$ ) were collected from laboratory stock culture (average room temperature $25^{\circ} \mathrm{C}$ ) and divided into 5 groups, each group comprising of 5 individuals. The first 3 groups of worms were allowed to remain in dark places (to avoid effect of light) in oven-dried soils kept inside the earthen pots and being covered by porous cloth for $2 \mathrm{hrs}$ (Group I), $4 \mathrm{hrs}$ (Group II) and $6 \mathrm{hrs}$ (Group III) respectively. The group IV after experiencing $6 \mathrm{hrs}$ of dehydration was transferred to a beaker containing distilled water for 4 hrs hydration. The rest 5 earthworms (Group V) kept in an earthen pot containing a bed of moist soil were considered as the control. The cerebral ganglia from both control and experimental groups were sacrificed and fixed in Bouin's fluid for 18 hours. Tissues were dehydrated in gradations of alcohol, cleared in xylene and embedded in paraffin wax $\left(58-60^{\circ} \mathrm{C}\right)$. Serial transverse sections ( $7 \mu \mathrm{m}$ thick), stretched on glass slides were stained with Gomori's Chrome Alum Haematoxylin Phloxin [6].

The nucleocytoplasmic (NP) ratios of the neurosecretory cells (10 cells of each type) were determined by measuring the maximum diameter of the perikaryon, as well as, the nucleus. Palcovit's formula $\left(\mathbf{V}=\frac{\pi}{6} \times \mathbf{L} \mathbf{D}^{2}\right)$ has been applied for calculation of nucleus and cell volume. The average value of the ratio $\frac{\mathbf{V n}}{\mathbf{V} \mathbf{c}-\mathbf{V n}}(\mathrm{Vn}=$ nuclear volume, $\mathrm{Vc}=$ cell volume $)$ has been considered to assess the neurosecretory activity.

\section{Results and discussion}

\subsection{Behavioural and Physiological changes}

Interesting behavioural changes in the E. eugeniae were recorded following dehydration and subsequent hydration. Following introduction of worms into totally dehydrated soils, they started to release mucus and lose water from the body to the soils. Within 1 to 2 hours of dehydration the worms get coiled and then clumped to form a mass, a physiological mean to decrease the surface area of the worms to prevent water loss from the body.

When the dehydrated earthworms were put into distilled water, there was rapid osmotic influx of water in the body, so they gradually swelled, gained their body weight, dispersed in water and became actively motile.

\subsection{Histomorphic Changes in Neurosecretory system}

\subsubsection{Control}

Frontal section of cerebral ganglia showed thick cortical tire of neurosecretory cells of two categories, small deep stained A cells chiefly located beneath the perineurium and large moderately stained B cells located close to the neuropile and beneath the peripheral layer of A cells (Fig1a). Both A and B neurosecretory cells show different phases of secretory activity as indicated by fluctuating content of neurosecretory materials.

While deep stained A cells possess colloidal secretion, the B cells contain numerous cytoplasmic vacuoles. "Zone of Accumulation" (Fig1b) in between cortical tire of neurosecretory cells and central neuropile had accumulation of Gomori positive neurosecretory materials.

\subsubsection{Experimental}

Group - I: (after 2 hours of dehydration)

The A and B cells irrespective of their types showed extensive depletion of neurosecretion indicating release of neurosecretory materials from the cells. The axonal transport of neurosecretion is evident (Fig2a), close to neuropile region. Accumulation of Gomori positive substances in the wall of blood vessels was also indicated. Most of the neurosecretory cells irrespective of their types had voluminous axon oriented nuclei with phloxinophilic nucleoli (Fig2b). Both A and B neurosecretory cells had significant increase $(\mathrm{P}<0.05)$ in nucleocytoplasmic $(\mathrm{NP})$ indices compared to those of control (Table-1).

Group -II: (after 4 hours of dehydration)

The neurosecretory cells of mid dorsal region of cerebral ganglia showed extensive depletion with shrinkage of perikarya leading to loss of cellular conformity probably due to desiccational water loss from the body (Fig3a). In the postero lateral part of the cerebral ganglia there was appearance of deep stained A cells with accumulation of neurosecretory material (Fig3b). Axonal transport from the A cell was also indicated. The B cells close to neuropile on 
the other hand, had extensive depletion coupled with enormous cytoplasmic vacuolation. The B neurosecretory cells had very large nuclei with distinct nucleolus (Fig3 a and b). A cells had significant increase $(\mathrm{P}<0.05)$ in $\mathrm{NP}$ indices compared to those of control and 2 hrs of dehydration stress. NP indices of B cells were significantly higher $(\mathrm{P}<0.05)$ but at par with those of 2 hrs dehydration stress.

\section{Group -III: (after 6 hours of dehydration)}

Deep stained A neurosecretory cells almost disappeared. All the moderately stained B cells showed cytoplasmic vacuoles (Fig4) along with secretion around (floccules) so as to display spongy appearance of the perikarya. Some of the B cells displayed cracky texture of cytoplasm. There was appearance of Gomori positive substances outside the perineurium. Extra cerebral Gomori positive cells were recorded. NP indices of A cells after 6hrs of dehydration decreased significantly $(\mathrm{P}<0.05)$ compared to those of 4 hrs of dehydration, but were at par with those of control. In contrast, NP indices of B cells after 6hrs of dehydration significantly increased compared to those of $2 \mathrm{hrs}$ and $4 \mathrm{hrs}$ of dehydration stress.

\section{Group -IV: (after 4 hours of hydration following 6 hours dehydration)}

Reappearance of A neurosecretory cells with accumulation of neurosecretion was observed. Large B type cells showed axon oriented nuclei with accumulation of coarse secretion along with cytoplasmic vacuoles (Fig5). Accumulation of coarse Gomori positive neurosecretory inclusions around the nucleus was recorded (Fig5). NP indices (Table- 1) of A cells in 4 hrs hydrated worms following 6 hrs dehydration was at par with those of 6 hrs dehydrated worms. The NP indices of B cells in 4 hrs hydrated worms following 6 hrs dehydration, decreased significantly $(\mathrm{P}<0.05)$. Extra cerebral Gomori positive cells were visualized.
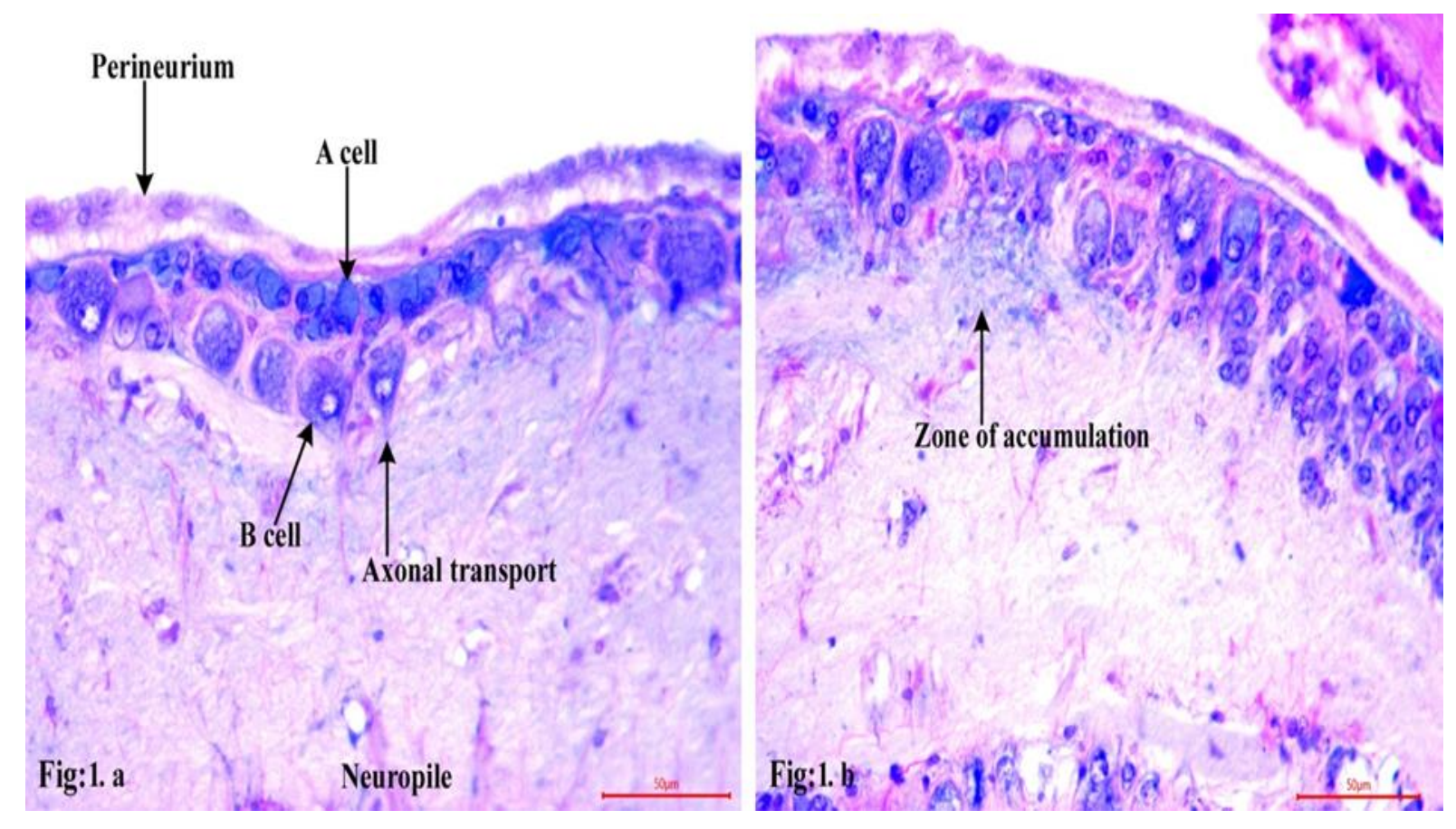

Figure 1 Frontal sections showing the distribution of CAHP positive neurosecretory cells with axonal transport (1a) and "accumulation zone" in the cerebral ganglia (1b) in the control earthworms (X400). 

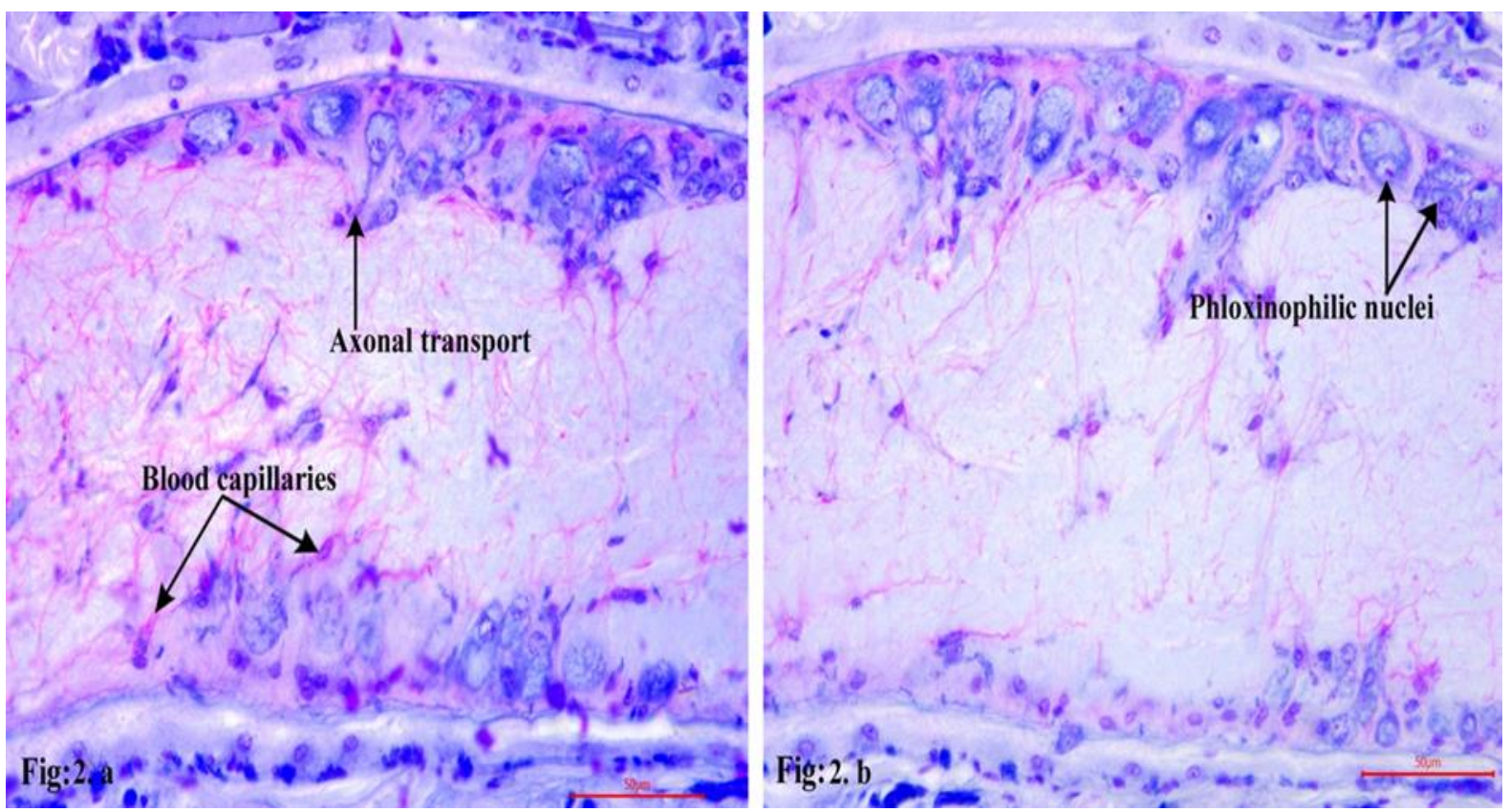

Figure 2 Frontal sections showing axon oriented CAHP positive neurosecretory cells (2a) and neurosecretory cells with phloxinophilic nuclei (2b) after 2 hours of dehydration (X400).
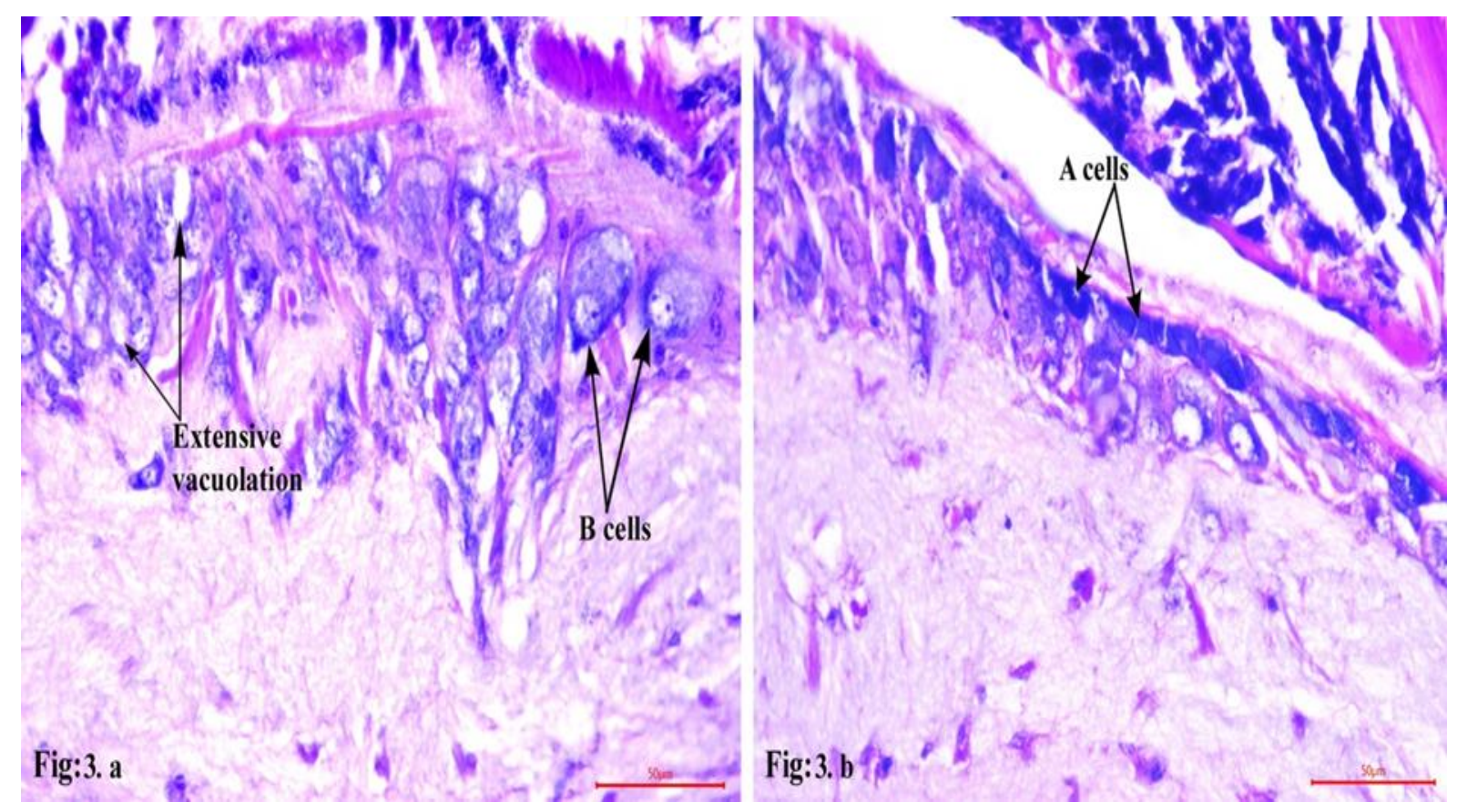

Figure 3 Frontal sections showing the large 'B neurosecretory cells' with extensive vacuolation (3a) and deeply CAHP stained 'A cells' (3b) after 4 hours of dehydration (X400). 


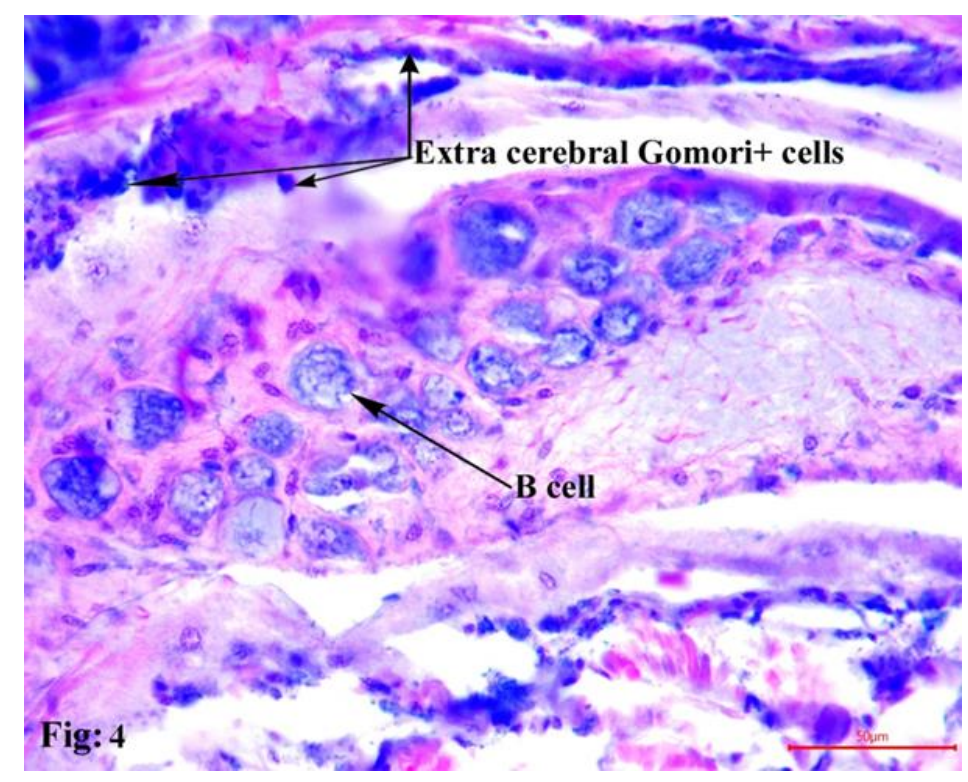

Figure 4 Frontal section showing the large 'B neurosecretory cell' with extensive cytoplasmic vacuolation and extra cerebral Gomori positive cells after 6 hours of dehydration (X400).

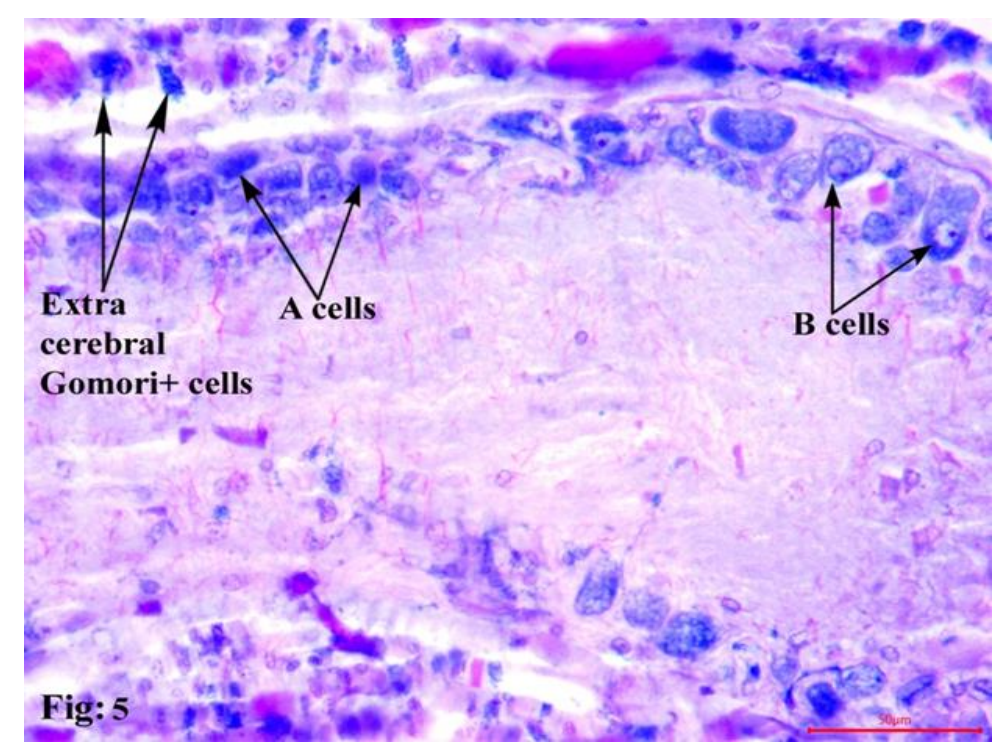

Figure 5 Frontal section showing CAHP positive 'A' and 'B' neurosecretory cells and extra cerebral Gomori positive cells after 4 hours of hydration following 6 hours dehydration (X400). 
Bhattacharjee and Chaudhuri/ GSC Biological and Pharmaceutical Sciences, 2020, 11(02), 053-060

Table 1 Showing effects of dehydration and subsequent hydration on cerebral neurosecretory cells of earthworm, Eudrilus eugeniae

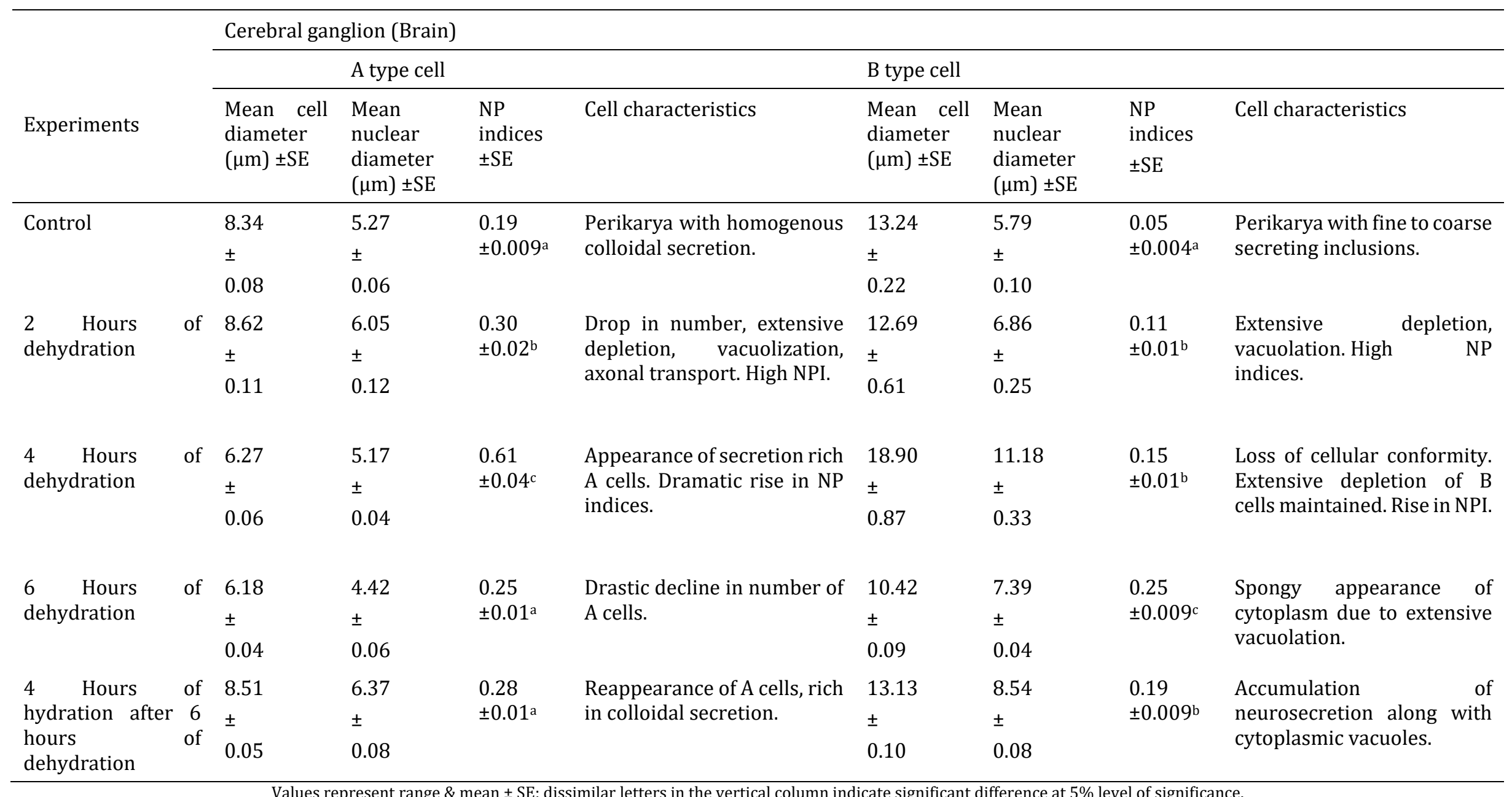

Values represent range \& mean \pm SE; dissimilar letters in the vertical column indicate significant difference at $5 \%$ level of significance. 


\section{Discussion}

Dehydration stress brings about differential secretory activities in type A and B neurosecretory cells in the cerebral ganglia of tropical earthworm, Eudrilus eugeniae. Extensive depletion of A type neurosecretory cells (so as to assume their disappearance) following 2 hrs of dehydration and accumulation of Gomori positive substances i.e. neurosecretory materials in them (reappearance) after $4 \mathrm{hrs}$ dehydration followed again by depletion of secretory substances in the $\mathrm{A}$ cells after 6 hrs dehydration stress indicates secretory dynamics in A type cells during super elevation in the osmotic concentration of the body fluid in the earthworm. The B type cells on the other hand, had extensive depletion evidenced by appearance of cytoplasmic vacuoles, floccules and cracky texture of cytoplasm. Hanumante and Nagabhushanam [7] and Chaudhuri and Chaudhuri [8] also reported extensive depletion of neurosecretion and cracky texture of cytoplasm in the cerebral neurosecretory cells following dehydration stress in earthworms, Perionyx excavatus (Megascolecidae) and Eutyphoeus gammiei (Octochaetidae) respectively. These characteristics indicate functional attributes of cerebral A and B neurosecretory cells in E. eugeniae especially when possible 'super-elevation' in the osmotic concentration of the body fluid is accounted for. According to Chaudhuri and Banik [9] neurosecretory A cells and B cells correspond to peptidergic and aminergic neurones in the central nervous system of earthworm. According to Zimmermann [10], both aminergic and peptidergic neurons of the supraoesophagal ganglia are considered to be indispensable for regulation of the osmotic balance in dehydrated worms, Lumbricus terrestris. Later, Carley [11] found that in L. terrestris the neurosecretory principle from brain influences osmotic and ionic regulation by changing the functional activities of integument or nephridia in dehydrated worm.

Depletion of neurosecretory materials from cerebral neurosecretory cells of Eudrilus eugeniae probably indicates elaboration of "antidiuretic hormone" to combat osmotic stress. It is likely that cytopathological changes such as extensive vacuolation and cracky texture of cytoplasm in the neurosecretory cells are due to exposure of the worm to acute dehydration stress. Earlier, Aros and Vigh [12] related these cytological changes in the neurosecretory cells to their possible holocrine secretion to counteract the said stress action. After transfer of dehydrated (6 hrs) earthworms to distilled water, the desiccation stress is mitigated due to rapid influx of water within the body through skin. Hence, upon hydration there is an increase in the number of deep stained A cells and accumulation of neurosecretion in both $\mathrm{A}$ and B neurosecretory cells. Thus, the present results point out that the cerebral A and B neurosecretory cells are possibly involved in the regulation of osmotic balance in the tropical earthworm, Eudrilus eugeniae which has to combat seasonal osmotic stress of dehydration and hydration during summer and monsoon.

\section{Conclusion}

The result indicates that cerebral neurosecretory cells (A and B cells) are possibly involved in the regulation of osmotic balance in earthworm, Eudrilus eugeniae subjected to dehydration and hydration stress.

\section{Compliance with ethical standards}

\section{Acknowledgments}

Authors thankfully acknowledge Prof. B. K. Agarwala (Ex. head) for the kind cooperation and constant encouragement during carrying out of the research.

\section{Disclosure of conflict of interest}

In the submission of research paper, there is no conflict of interest between the first author, Anurag Bhattacharjee and the second author (corresponding author), P.S. Chaudhuri. Both the authors contributed to this paper. The first author carried out the research during M. Sc dissertation and the second author guided the research and corrected the manuscript.

\section{Statement of ethical approval}

Tripura University Animal Ethics Committee allows research works on earthworm species as they are cultured under laboratory conditions. 


\section{References}

[1] Kale RD and N Karmegam. (2010). The role of earthworms in tropics with emphasis on Indian ecosystems. Appl. Environ, Soil Sci, 56, 41-43.

[2] Aros B and E Bodnar. (1960). Histologisch Untersuchungen iiber die neurohumorale Funktion von Eisenia rosea (Oligochaeta). Symp. Biol. Hung, 1, 191-202.

[3] Takeuchi N. (1980). Effects of brain removal on the osmotic and ionic concentration of the coelomic fluid. Comp Biochem Physiol A Comp Physiol, 67, 347-352.

[4] Gates GE. (1972). Burmese Earthworms. An introduction to the systematics and biology of megadrile oligochaetes with special reference to South East Asia. Trans. Am. Philo. Soc, 62 (7), 1-326.

[5] Dominguez J, Edwards CA and Ashby J. (2001). The biology and ecology of Eudrilus eugeniae (Kinberg) (Oligochaeta) bred in cattle wastes. Pedobiologia, 45, 341-353.

[6] Bargmann W. (1949). Über die neurosekretorische Verknüpfung von Hypothalamus und Neurohypophyse. Z. Zellforsch, 34, 610-634.

[7] Hanumante MM and Nagabhushanam R. (1977). Effect of brain extirpation on blood chloride of the earthworm, Perionyx excavatus. Comp. Physiol. Ecol, 2, 107-108.

[8] Chaudhuri D and Chaudhuri PS. (1993). Cytomorphic changes in the brain neurosecretory cells of Indian earthworm, Eutyphoeus gammiei exposed to dehydration and subsequent hydration. Proc Zool Soc, 46, 105-111.

[9] Chaudhuri PS and Banik D. (2015) Cytology and Histology of the Cerebral Neurosecretory Systems in some Tropical Earthworm Species. J Cytol Histol, 6, 1-7.

[10] Zimmermann P. (1971). Die Zentralnervöse Kontrolle der dehydration bei Lumbricus terrestris L; Z. Zellforsch, 112, 551- 571.

[11] Carley WW. (1975). Effect of brain removal on integumental water permeability and ion content of the earthworm, Lumbricus terrestris L. Gen. Comp. Endocrinol, 27, 509-516.

[12] Aros B, Vigh B. (1962). Regeneration of the neurosecretory system of the cerebral ganglion in the earthworm Lumbrieus terrestris. Acta. Biol. Acad. Sci, Hungaricae, 13(3), 323-337.

\section{How to cite this article}

Bhattacharjee A and Chaudhuri P. (2020). Effects of dehydration and subsequent hydration stress on the cerebral neurosecretory cells of Eudrilus eugeniae (Kinberg, 1867). GSC Biological and Pharmaceutical Sciences, 11(2), 53-60. 